\title{
Effects of prepartum 2,4-thiazolidinedione on insulin sensitivity, plasma concentrations of tumor necrosis factor- $\alpha$ and leptin, and adipose tissue gene expression
}

\author{
K. M. Schoenberg, ${ }^{\star}$ K. L. Perfield, ${ }^{* 1}$ J. K. Farney, $\dagger$ B. J. Bradford, $†$ Y. R. Boisclair, ${ }^{\star}$ and T. R. Overton ${ }^{\star 2}$ \\ *Department of Animal Science, Cornell University, Ithaca, NY 14853 \\ †Department of Animal Sciences and Industry, Kansas State University, Manhattan 66506
}

\section{ABSTRACT}

Administration of peroxisome proliferator-activated receptor gamma (PPAR $\gamma)$ ligands, thiazolidinediones (TZD), to prepartum dairy cattle has been shown to improve dry matter intake and decrease circulating nonesterified fatty acids (NEFA) around the time of calving. The objective of this work was to elucidate mechanisms of TZD action in transition dairy cattle by investigating changes in plasma leptin, tumor necrosis factor- $\alpha(\mathrm{TNF} \alpha)$, the revised quantitative insulin sensitivity check index (RQUICKI), and adipose tissue gene expression of leptin, PPAR $\gamma$, lipoprotein lipase (LPL), and fatty acid synthase (FAS). Multiparous Holstein cows $(\mathrm{n}=40)$ were administered $0,2.0$, or $4.0 \mathrm{mg}$ of $\mathrm{TZD} / \mathrm{kg}$ of body weight (BW) by intrajugular infusion once daily from $21 \mathrm{~d}$ before expected parturition until parturition. Plasma samples collected daily from $22 \mathrm{~d}$ before expected parturition through $21 \mathrm{~d}$ postpartum were analyzed for glucose, NEFA, and insulin. Plasma samples collected on $\mathrm{d}-14,-3,-1,1,3,7,14$, and 49 relative to parturition were also analyzed for leptin and TNFa. Adipose tissue was collected on d 7 before expected parturition from a subset of cows, and gene expression was examined via quantitative real-time PCR. A tendency for a treatment by time effect on plasma leptin prepartum was observed such that values were similar on $\mathrm{d}-14$ but cows receiving $2.0 \mathrm{mg} / \mathrm{kg}$ of BW of TZD tended to have lower circulating leptin as calving approached. Postpartum leptin tended to be increased linearly $(2.3,2.4$, and $2.5 \pm 0.1 \mathrm{ng} / \mathrm{mL}$ for $0,2.0$, and $4.0 \mathrm{mg} / \mathrm{kg}$ treatments, respectively) in cows that received TZD prepartum. Plasma TNFo increased linearly $(2.6,3.7$, and $4.0 \pm 0.1 \mathrm{pg} / \mathrm{mL})$ in response to TZD treatment and decreased through the first week postpartum. Calculation of RQUICKI $\{1 /[\log$ (glucose)

Received April 30, 2011.

Accepted July 15, 2011.

${ }^{1}$ Current address: Elanco Animal Health, 2500 Innovation Way, Greenfield, IN 46140.

${ }^{2}$ Corresponding author: tro $2 @$ cornell.edu $+\log ($ insulin $)+\log (\mathrm{NEFA})]\}$ suggested altered insulin sensitivity in cows administered TZD that may depend on day relative to calving. Administration of TZD increased adipose tissue expression of PPAR $\gamma$ mRNA $(11.0,13.3$, and $12.8 \pm 1.9)$. Administration of TZD had a quadratic effect on gene expression of leptin (16.2, 10.7, and $17.4 \pm 1.6$ ) and no effect on LPL expression, and expression of FAS was lower for TZD-treated cows than for controls $(8.2,4.2$, and $6.1 \pm 1.8$, respectively). Results imply altered expression and plasma concentrations of leptin, increased plasma TNF $\alpha$ concentrations, and increased expression of PPAR $\gamma$ in adipose tissue as potential mechanisms for the effects of TZD administration on transition dairy cattle.

Key words: transition period, thiazolidinedione, peroxisome proliferator-activated receptor- $\gamma$, tumor necrosis factor- $\alpha$

\section{INTRODUCTION}

The overall profitability and health of a dairy cow benefits from successful management during the transition period (Drackley, 1999). The metabolic adaptations that support the onset of lactation include increased mobilization of fatty acids from adipose tissue and increased hepatic gluconeogenesis (Bell, 1995). Orchestration of nutrient partitioning is necessary to meet new metabolic demands corresponding to a simultaneous decrease in DMI around calving, which requires mobilization of body fat reserves (Bauman and Currie, 1980). These responses increase circulating NEFA, which, when taken up by the liver in excess, predispose cows to accumulate triglyceride in liver and increase the risk for fatty liver and other disorders such as ketosis, milk fever, retained placenta, and mastitis (Drackley et al., 2001).

Although much research has focused on the ability of the liver to process NEFA (Drackley et al., 2001; Bobe et al., 2004), the potential may also exist to reduce the fatty acid load to the liver by modulating the spike in circulating NEFA that occurs during the immediate postpartum period. Part of the homeorhetic adaptation 
that occurs from late pregnancy to early lactation is insulin resistance of peripheral tissues, including adipose, to spare glucose for the mammary gland (Bell and Bauman, 1997). Although this is beneficial to support lactation, excessive insulin resistance of adipose tissue likely results in disproportionately high NEFA levels (Vernon, 2005). Opportunities to target adipose tissue to modulate insulin resistance may benefit transition cow health.

Insulin-sensitizing agents have been used for the treatment of Type II diabetes in humans for several years (Hammarstedt et al., 2005). Popular drugs used are those belonging to the thiazolidinedione (TZD) family of synthetic peroxisome proliferator-activated receptor- $\gamma$ (PPAR $\gamma$ ) ligands (Guo and Tabrizchi, 2006). Peroxisome proliferator-activated receptors are ligand-activated transcription factors that are involved in energy status and that modulate inflammatory responses (Yki-Jarvinen, 2004). Specifically, PPAR $\gamma$ is a major regulator of adipogenesis and has been characterized to be abundant in the adipose tissue of ruminants (Sundvold et al., 1997; Harvatine and Bauman, 2007).

The first group to treat ruminants with TZD used it to reverse tumor necrosis factor- $\alpha$ ( $\mathbf{T N F} \boldsymbol{\alpha})$-induced insulin resistance in steers (Kushibiki et al., 2001). Treatment with TZD partially reversed the insulin resistance caused by TNF $\alpha$ administration as demonstrated by decreased response of plasma insulin to glucose infusion, and an increased response in plasma glucose to insulin challenges in cows administered TZD (Kushibiki et al., 2001). Kushibiki et al. (2001) illustrated the potential use of TZD in ruminants to attenuate insulin resistance. Additionally, TZD appeared to enhance peripheral tissue sensitivity to insulin without dramatically affecting circulating levels of insulin.

In the first study involving transition dairy cattle, cows were treated with either 0.0 or $4.0 \mathrm{mg}$ of TZD/ $\mathrm{kg}$ of BW by intravenous infusion once daily from 25 d before expected parturition until parturition (Smith et al., 2007). The results of this initial experiment indicated that cows treated prepartum with TZD had decreased NEFA during the pre- and peripartum periods and increased DMI in the postpartum period (Smith et al., 2007). This suggested the potential for the use of TZD in transition dairy cattle to mitigate the dramatic decrease in intake and concurrent increase in NEFA that occur postcalving.

The results discussed below are from a second study in transition dairy cattle (Smith et al., 2009). Similar to results from the first TZD-transition cow study, plasma NEFA were lower in the postpartum period in TZD-treated cows and peripartal DMI was higher (Smith et al., 2009). Linear decreases were observed in postpartum liver concentrations of triglycerides and in the ratio of liver triglycerides:glycogen (Smith et al., 2009). Based on these results, it was of interest to explore further the potential mechanisms for these beneficial effects of TZD administration on transition cow metabolism. The objectives of the current study were to determine the effect of prepartum TZD administration on plasma leptin, plasma $\mathrm{TNF} \alpha$, a calculated index of insulin sensitivity, and adipose tissue mRNA abundance for genes involved in lipid metabolism.

\section{MATERIALS AND METHODS}

\section{Animals, Treatments, and Sampling}

All procedures involving animals were approved before the onset of the experiment by the Cornell University Institutional Animal Care and Use Committee. This experiment was part of a larger experiment that commenced in September 2006 and was completed in March 2007 (Smith et al., 2009). Detailed materials and methods can be found in the previously published work (Smith et al., 2009). In brief, Holstein cows ( $\mathrm{n}=$ 40) entering second or greater lactation that had been dried off at approximately $60 \mathrm{~d}$ before expected calving were selected from the Cornell Teaching and Research Center dairy herd and moved to individual tie stalls at approximately $32 \mathrm{~d}$ before expected calving.

Cows were fitted with a single indwelling jugular catheter (Micro-Renathane Implantation Tubing, 2.03 mm o.d. $\times 1.02 \mathrm{~mm}$ i.d.; Braintree Scientific Inc., Braintree MA) 23 d before expected calving date. At $21 \mathrm{~d}$ before expected parturition, cows were assigned to 1 of 3 treatments in a randomized complete block design and administered TZD at 1 of 2 doses (2.0 or 4.0 $\mathrm{mg} / \mathrm{kg}$ of $\mathrm{BW} ; \mathrm{n}=13$ and 14 , respectively) or saline (control; $\mathrm{n}=13$ ) by intrajugular infusion once daily at $1200 \mathrm{~h}$ until parturition. Thiazolidedione was obtained as 2,4-thiazolidinedione from Sigma Chemical Co. (St. Louis, MO). Cows were assigned to treatments by balancing for BCS and previous calculated 305-d mature-equivalent milk yield. Cows were fed a common TMR for ad libitum intake during the pre- and postpartum periods that was formulated to meet or exceed predicted requirements for energy, protein, minerals, and vitamins (NRC, 2001).

Body weights and BCS were recorded once weekly beginning the week before treatment initiation until the end of the study. Body condition scores were assigned using a 5-point system, and the scores of 2 individuals were averaged as the value assigned to each cow (Wildman et al., 1982).

\section{Plasma and Tissue Sampling and Analysis}

Blood samples were collected immediately before treatment administration once daily at $1200 \mathrm{~h}$ via 
jugular catheter from $22 \mathrm{~d}$ before expected parturition to parturition. Following parturition, blood samples were collected daily via venipuncture of the coccygeal vessels until $21 \mathrm{~d}$ postpartum and then twice per week from wk 4 through 9 of lactation. Blood samples were transferred into glass test tubes containing sodium heparin (100 IU/mL of blood). Plasma was harvested following centrifugation $\left(2,800 \times g\right.$ for 15 min at $\left.4^{\circ} \mathrm{C}\right)$, snap-frozen in liquid $\mathrm{N}_{2}$, and stored at $-20^{\circ} \mathrm{C}$ until analyses for metabolites. Plasma concentrations of glucose were determined by enzymatic analysis (glucose oxidase) using a commercial kit (kit 510-A; Sigma Chemical). Plasma concentrations of NEFA also were analyzed by enzymatic analysis (NEFA-C; WAKO Pure Chemical Industries, Osaka, Japan) with modifications described by McCutcheon and Bauman (1986). Intraand interassay CV for plasma glucose and NEFA assays were as described previously (Smith et al., 2009). All spectrophotometric measurements were conducted using a Versamax tunable microplate reader (Molecular Devices, Sunnyvale, CA). Plasma concentrations of leptin on $\mathrm{d}-14,-3,-1,1,3,7,14$, and 49 relative to parturition were determined by double-antibody radioimmunoassay (Ehrhardt et al., 2000). Intra- and interassay CV for plasma leptin were 3.9 and $9.7 \%$, respectively. Plasma $\mathrm{TNF} \alpha$ concentrations from $\mathrm{d}-14$, $-3,-1,1,3,7,14$, and 49 relative to parturition were determined in duplicate by ELISA (Farney et al., 2011). The modified ELISA allowed for a TNFa detection range in bovine plasma from 2 to $250 \mathrm{pg} / \mathrm{mL}$ (Farney et al., 2011); intra- and interassay CV were 13.0 and $10.4 \%$, respectively.

Subcutaneous adipose tissue was collected from the tailhead region of a randomly selected subset of cows within each treatment group, before initiation of treatments and again $7 \mathrm{~d}$ before expected calving date (and thus after $14 \mathrm{~d}$ of TZD administration). Six cows were from the group administered saline, 5 cows were administered $2.0 \mathrm{mg}$ of $\mathrm{TZD} / \mathrm{kg}$ of $\mathrm{BW}$, and 4 were administered $4.0 \mathrm{mg}$ of $\mathrm{TZD} / \mathrm{kg}$ of $\mathrm{BW}$. Days before actual calving date averaged $5.8 \pm 3.8 \mathrm{~d}$ and ranged from 1 to $13 \mathrm{~d}$ before actual calving date. During biopsies, the area was brushed and clipped to remove excess hair and prepared with betadine surgical scrub $(7.5 \%$ povidone-iodine; Purdue Frederick, Stamford, CT) and $70 \%$ ethanol in water. Cows were administered $20 \mathrm{mg}$ of the sedative xylazine hydrochloride (Rompun $2 \%$, Bayer Inc., Sarnia, Ontario, Canada). A local anesthetic (Lidocaine $\mathrm{HCl} 2 \%$, Butler Animal Health, Dublin, $\mathrm{OH} ; 18 \mathrm{~mL}$ ) was injected subcutaneously around the biopsy site. The area below the spinal processes between the hips and the pins of the cow was palpated to locate an area with sufficient subcutaneous fat, a 4- to 8 -cm incision was made with a scalpel blade, and a small biopsy (0.5-1.5 g) was removed using sterile forceps and scalpel. The incision was closed with 6 to 10 surgical skin staples (3M Precise Vista Disposable Skin Stapler, 3M, St. Paul, MN) and treated with a topical antiseptic (BluKote aerosol spray, H. W. Naylor Co., Morris, NY). Adipose tissue samples were washed with sterile saline, cut into aliquots, placed into sterile and RNase-free vials, and quenched in liquid $\mathrm{N}_{2}$.

\section{Quantitative Real-Time PCR}

Analysis of mRNA abundance was done by quantitative real-time reverse transcription PCR. Ribonucleic acid was isolated from 150 to $200 \mathrm{mg}$ of adipose tissue using the RNAeasy Mini Kit (Qiagen, Valencia, CA) and on-column DNase digestion with the RNase-free DNase set (Qiagen) after homogenization in $1.0 \mathrm{~mL}$ of Qiazol (Qiagen) reagent. Ribonucleic acid concentration and integrity was determined using an Agilent 2100 BioAnalyzer (Agilent Technologies, Santa Clara, CA). Total RNA was reverse-transcribed using the High Capacity cDNA Reverse Transcription Kit with RNase Inhibitor (Applied Biosystems). Polymerase chain reactions were carried out using Power SYBR Green (Applied Biosystems), $25 \mathrm{ng}$ of total RNA (or $2.5 \mathrm{ng}$ of total RNA for $18 \mathrm{~S}$ ), and $400 \mathrm{nmol} / \mathrm{L}$ of gene-specific forward and reverse primers in a $25-\mu \mathrm{L}$ reaction volume using a 2-step program $\left(95^{\circ} \mathrm{C}\right.$ for $15 \mathrm{~s}$ followed by $60^{\circ} \mathrm{C}$ for $60 \mathrm{~s}$ ) on an ABI Prism 7000 sequence detection system (Applied Biosystems). 18S was used as a housekeeping gene, with mRNA abundance of all genes expressed relative to $18 \mathrm{~S}$. Selection of genes for expression analysis was based upon TZD being a known up-regulator of PPAR $\gamma$ (Guo and Tabrizchi, 2006), the role of leptin in signaling energy status in dairy cattle (Vernon et al., 2001), and the known roles of lipoprotein lipase (LPL) and fatty acid synthase (FAS) in fatty acid metabolism and as targets of TZD administration in other species (Kageyama et al., 2003; Bogacka et al., 2004). Primers used were published previously (Harvatine and Bauman, 2006; Thorn et al., 2006; Harvatine et al., 2009).

\section{Calculations and Statistical Analysis}

The relative insulin sensitivity measure, revised quantitative insulin sensitivity check index (RQUICKI), used in ruminants was calculated as follows (Holtenius and Holtenius, 2007):

$$
\text { RQUICKI }=1 /\left[\log \left(\mathrm{G}_{\mathrm{b}}\right)+\log \left(\mathrm{I}_{\mathrm{b}}\right)+\log \left(\mathrm{NEFA}_{\mathrm{b}}\right)\right],
$$

where $G_{b}=$ basal glucose $(\mathrm{mg} / \mathrm{dL}), \mathrm{I}_{\mathrm{b}}=$ basal insulin $(\mu \mathrm{U} / \mathrm{mL})$, and $\mathrm{NEFA}_{\mathrm{b}}=$ basal NEFA $(\mathrm{mmol} / \mathrm{L})$, such that a lower RQUICKI suggests greater insulin resistance. 
Statistical analyses were conducted as ANOVA on measures conducted over time (plasma concentrations, BCS) using the PROC MIXED procedure (SAS Institute Inc., Cary, NC) for a completely randomized design with repeated measures. Nine cows were removed from the data set for peri- and postpartum data as detailed in Smith et al. (2009). Pretreatment values for plasma variables, gene expression, and BCS assessed during the week before assignment to treatments were used as covariates during analysis of covariance applied to their corresponding measurements during the treatment period. The statistical model included fixed effects of covariate, treatment, time, and the interaction of treatment and time. The random effect was cow nested within treatment. For each variable, 6 covariance structures were evaluated (first-order autoregressive, heterogeneous first-order autoregressive, compound symmetry, heterogeneous compound symmetry, firstorder ante-dependence, and unstructured), and the structure with the smallest Akaike's information criterion was selected. The method of Kenward-Rogers was used for calculation of denominator degrees of freedom. Covariates were dropped from the statistical model if $P$ $>0.15$ and the data were reanalyzed. Data were evaluated on assumptions of normality and outliers were determined (according to Studentized residuals $>3.0$ or $<-3.0$ ), removed from the data set, and data reanalyzed. In all cases except for TNFo, prepartum (d -21 to -1 , or -14 and $-3 \mathrm{~d}$ in the case of plasma leptin), peripartum ( $\mathrm{d}-7$ to +7$)$, and postpartum data were analyzed separately, consistent with Smith et al. (2009). Plasma TNF $\alpha$ data were also transformed $\{[\log (\mathrm{TNF} \alpha)$ $+1]\}$ to satisfy the requirement for normal distribution of residuals; data shown are back-calculated from least squares means of transformed data. For TNFo, statistical analysis was performed on data compiled for the prepartum $(\mathrm{d}-14)$, transition $(\mathrm{d}-3$ to +3$)$, and postpartum periods $(\mathrm{d}+7$ to +49$)$. As the effect of period was significant $(P<0.05)$, preplanned orthogonal contrasts were performed between the prepartum period and the transition period, the prepartum and postpartum periods, and the transition period versus all other periods. Gene expression data were analyzed using the MIXED procedure of SAS, including the effects of treatment. Day relative to actual calving date and BCS were evaluated for significance as covariates and removed if $P>0.15$. Expression data were evaluated relative to reference gene (18S) expression.

\section{RESULTS}

Results related to daily plasma values for NEFA, glucose, and insulin and production levels were as reported previously (Smith et al., 2009). As reported, TZD administration during the prepartum period resulted in a quadratic effect in prepartum plasma NEFA such that cows receiving $2.0 \mathrm{mg}$ of $\mathrm{TZD} / \mathrm{kg}$ of $\mathrm{BW}$ had higher NEFA $(171 \mu \mathrm{Eq} / \mathrm{L})$ than either the control cows (128 $\mu \mathrm{Eq} / \mathrm{L}$ ) or those receiving $4.0 \mathrm{mg}$ of $\mathrm{TZD} / \mathrm{kg}$ of $\mathrm{BW}$ $(118 \mu \mathrm{Eq} / \mathrm{L})$. Although no effects on plasma NEFA were observed during the peripartum period (all 3 treatment groups averaged $260 \pm 26 \mu \mathrm{Eq} / \mathrm{L}$ ), prepartum TZD linearly decreased plasma NEFA during the postpartum period $(348,331$, and $268 \mu \mathrm{Eq} / \mathrm{L}$ for the cows receiving $0.0,2.0$, and $4.0 \mathrm{mg}$ of $\mathrm{TZD} / \mathrm{kg}$ of $\mathrm{BW}$, respectively). Administration of TZD prepartum resulted in higher glucose concentrations for cows administered $4.0 \mathrm{mg}$ of $\mathrm{TZD} / \mathrm{kg}$ of BW during the pre- $(66.1 \mathrm{mg} / \mathrm{dL}$ vs. 64.3 and $66.0 \mathrm{mg} / \mathrm{dL}$ for the cows receiving 0.0 and $2.0 \mathrm{mg}$ of TZD $/ \mathrm{kg}$ of BW, respectively) and peripartum (61.1 $\mathrm{mg} / \mathrm{dL}$ vs. 57.9 and $57.8 \mathrm{mg} / \mathrm{dL}$, respectively) periods. Administration of TZD had no effect on plasma insulin concentrations in these cows. Prepartum plasma insulin levels averaged $1.24 \pm 0.09 \mathrm{ng} / \mathrm{mL}$ for all 3 treatment groups, whereas peripartum values averaged $0.88 \pm$ $0.07 \mathrm{ng} / \mathrm{mL}$ and postpartum values averaged $0.69 \pm$ $0.07 \mathrm{ng} / \mathrm{mL}$.

Figure 1 illustrates a potential treatment by day interaction $(P=0.09)$ of prepartum plasma leptin such that cows receiving $2.0 \mathrm{mg}$ of $\mathrm{TZD} / \mathrm{kg}$ of $\mathrm{BW}$ prepartum had the lowest concentration of plasma leptin as calving approached. Treatment had no effect on plasma leptin $(P=0.76)$ during the peripartum period and no treatment by day interaction $(P=0.57)$ was observed, but plasma leptin decreased as calving approached and remained low through $\mathrm{d}+7$ (data not shown). Postpartum plasma leptin tended $(P=0.14)$ to be increased linearly in response to TZD treatment as shown in Figure 2, without significant interaction of day and treatment $(P=0.65)$. Plasma TNFo was increased linearly from $\mathrm{d}-14$ through $\mathrm{d}+49$ relative to calving date $(P=0.01$; Figure 3$)$ in response to TZD treatment and decreased $(P=0.001$, Figure 4$)$ during the first week postpartum. No significant interaction of treatment and day was found in terms of plasma $\mathrm{TNF} \alpha$ response $(P=0.68)$. Contrasts of the effect of period showed that prepartum TNFo was significantly different from that in both the immediate peripartal period $(P<0.01)$ and the postpartum period $(P<0.0001)$.

An interaction $(P=0.09)$ of TZD administration and day was found during the peripartum period such that cows receiving $2.0 \mathrm{mg}$ of $\mathrm{TZD} / \mathrm{kg}$ of $\mathrm{BW}$ had lower RQUICKI prepartum, whereas cows receiving $4.0 \mathrm{mg}$ of $\mathrm{TZD} / \mathrm{kg}$ of BW had higher RQUICKI closer to calving (Figure 5). Additionally, a main effect of day $(P<$ 0.0001 ) was observed such that RQUICKI was lowest 


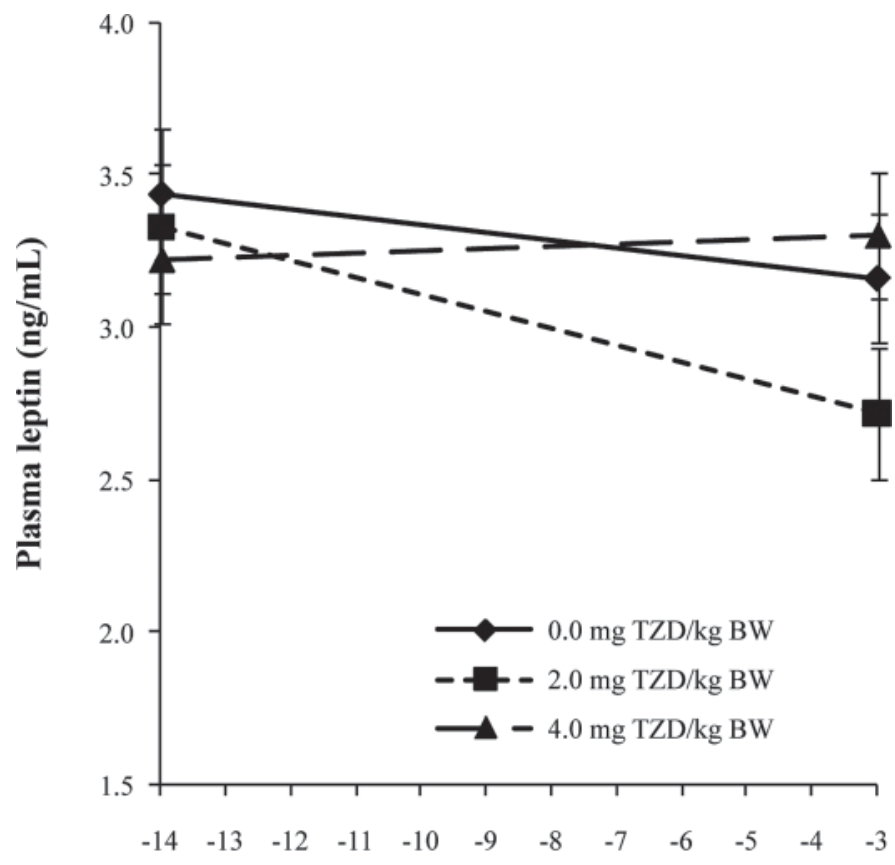

Day relative to parturition

Figure 1. Prepartum plasma leptin of cows administered increasing amounts of thiazolidinediones (TZD) during the prepartum period. Data shown are plasma values from $\mathrm{d}-14$ and $\mathrm{d}-3$ relative to calving date. Values represent least squares means, with error bars representing the SEM; $\mathrm{n}=13$ for $0.0 \mathrm{mg}$ of TZD $/ \mathrm{kg}$ of $\mathrm{BW}, \mathrm{n}=13$ for $2.0 \mathrm{mg}$ of TZD $/ \mathrm{kg}$ of $\mathrm{BW}$, and $\mathrm{n}=14$ for $4.0 \mathrm{mg}$ of TZD $/ \mathrm{kg}$ of $\mathrm{BW}$. The $P$-value for treatment by day interaction was 0.09 and effect of day was 0.04 .

around the time of calving. Postpartum RQUICKI was not affected by prepartum TZD administration $(P=$ $0.54)$.

Cows administered TZD had greater adipose tissue expression of mRNA for PPAR $\gamma$ compared with control cows $(P=0.01$; Table 1$)$. A quadratic effect of TZD $(P$ $=0.04$, treatment; $P=0.07$, quadratic; Table 1$)$ was found on adipose tissue gene expression of leptin such that cows administered $2.0 \mathrm{mg}$ of TZD $/ \mathrm{kg}$ of $\mathrm{BW}$ had the lowest leptin mRNA expression. Administration of TZD had no effect on adipose tissue gene expression for LPL $(P=0.28)$, but did affect FAS $(P=0.03$; Table 1$)$ such that cows receiving 2.0 and $4.0 \mathrm{mg}$ of $\mathrm{TZD} / \mathrm{kg}$ of BW had lower (0.42 and $0.61 \pm 0.18$, respectively) FAS expression than control cows $(0.82 \pm 0.18)$.

\section{DISCUSSION}

Dynamic metabolic changes occur around the time of parturition in dairy cattle (Bell, 1995). These changes include altered levels of plasma hormones such as leptin, changes in insulin resistance, and regulation of adipose tissue gene expression. In this study, prepartum TZD administration increased peripartal DMI

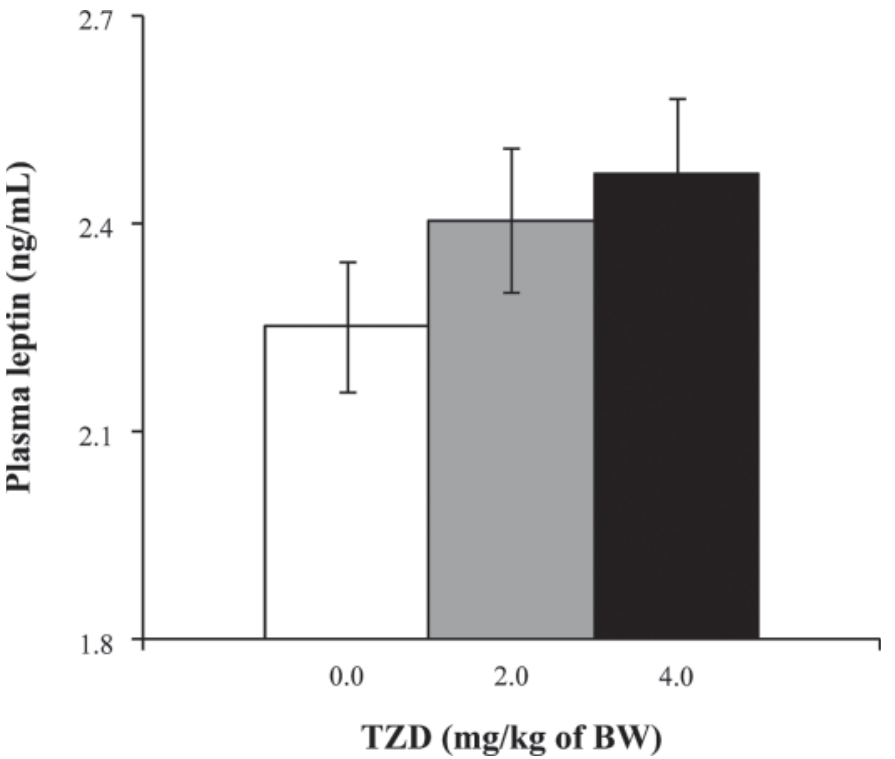

Figure 2. Postpartum plasma leptin of cows administered increasing amounts of thiazolidinediones (TZD) during the prepartum period. Data shown are average plasma values from $d+1$ through $d+49$ relative to calving date. Values represent least squares means, with error bars representing the SEM; $\mathrm{n}=12$ for $0.0 \mathrm{mg}$ of TZD $/ \mathrm{kg}$ of $\mathrm{BW}, \mathrm{n}=$ 10 for $2.0 \mathrm{mg}$ of TZD $/ \mathrm{kg}$ of BW, and $\mathrm{n}=9$ for $4.0 \mathrm{mg}$ of TZD $/ \mathrm{kg}$ of $\mathrm{BW}$. The $P$-value for a linear effect of treatment was 0.14 .

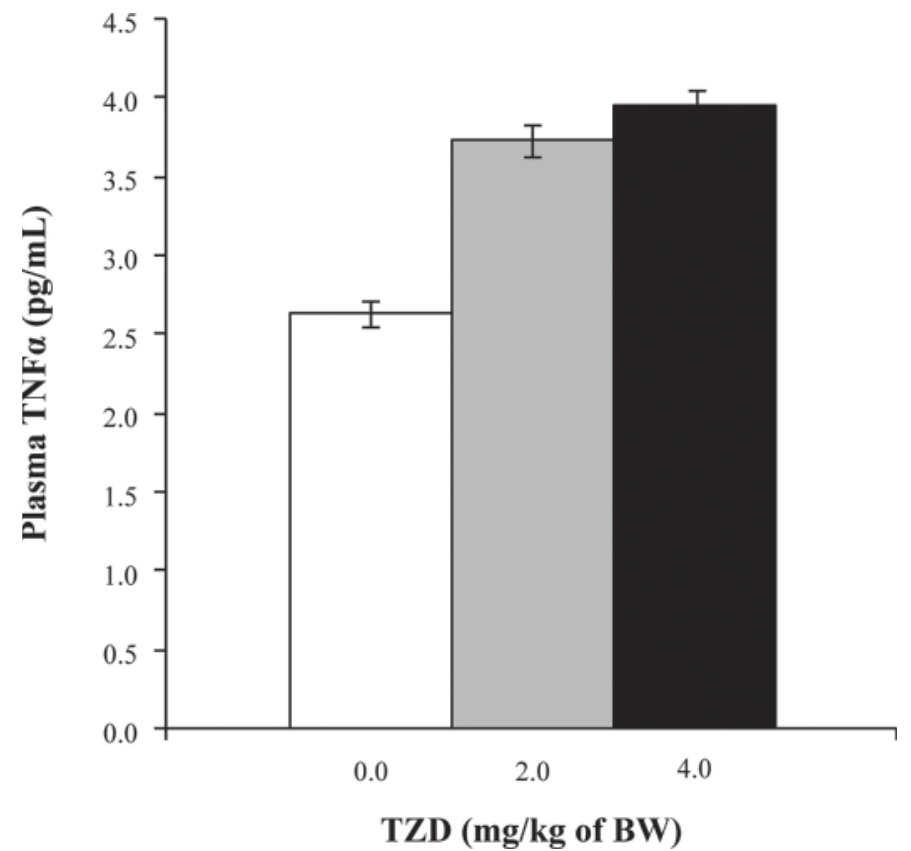

Figure 3. Pre- and postpartum plasma tumor necrosis factor- $\alpha$ $(\mathrm{TNF} \alpha)$ of cows administered increasing amounts of thiazolidinediones (TZD) during the prepartum period. Data shown are average plasma values from $\mathrm{d}-14$ through $\mathrm{d}+49$ relative to calving date. Values represent least squares means, with error bars representing the SEM; $\mathrm{n}=12$ for $0.0 \mathrm{mg}$ of TZD $/ \mathrm{kg}$ of BW, $\mathrm{n}=10$ for $2.0 \mathrm{mg}$ of TZD $/ \mathrm{kg}$ of $\mathrm{BW}$, and $\mathrm{n}=9$ for $4.0 \mathrm{mg}$ of TZD $/ \mathrm{kg}$ of $\mathrm{BW}$. The $P$-value for a linear effect of treatment was 0.01 
Table 1. Effects of thiazolidinedione (TZD) administration on adipose tissue gene expression ${ }^{1}$

\begin{tabular}{|c|c|c|c|c|c|c|c|}
\hline Gene $^{2}$ & \multicolumn{3}{|c|}{ TZD $(\mathrm{mg} / \mathrm{kg}$ of BW) } & SEM & \multicolumn{3}{|c|}{$P$-value } \\
\hline $\operatorname{PPAR} \gamma$ & 1.10 & 1.33 & 1.28 & 0.19 & 0.01 & 0.60 & 0.68 \\
\hline Lipoprotein lipase & 1.07 & 1.00 & 1.08 & 0.22 & 0.20 & - & - \\
\hline Fatty acid synthase & 0.82 & 0.42 & 0.61 & 0.18 & 0.03 & 0.41 & 0.23 \\
\hline
\end{tabular}

${ }^{1}$ Cows received a prepartum treatment of $0.0 \mathrm{mg}$ of TZD $/ \mathrm{kg}$ of BW $(\mathrm{n}=6), 2.0 \mathrm{mg}$ of TZD $/ \mathrm{kg}$ of BW $(\mathrm{n}=5)$, or $4.0 \mathrm{mg}$ of TZD/kg of BW (n $=4$ ) from $21 \mathrm{~d}$ before expected parturition through parturition.

${ }^{2}$ Values expressed are relative mRNA abundance, in relationship to a housekeeping gene (18S); PPAR $\gamma=$ peroxisome proliferator-activated receptor- $\gamma$.

and decreased postpartum plasma NEFA, indicative of improved metabolic health (Smith et al., 2009). The results reported herein indicate additional effects on plasma leptin, relative changes in insulin sensitivity, and limited effects on adipose tissue mRNA expression of key genes involved in lipid metabolism.

Known as a signal of adiposity in many species, leptin has the ability to increase energy expenditure and protect tissues from accumulation of excess lipid (Vernon et al., 2001). Plasma leptin concentration decreases as calving approaches and remains low throughout early lactation, as shown previously (Block et al., 2001; Liefers et al., 2003) and as described in the current study. During the prepartum period, cows treated with 2.0

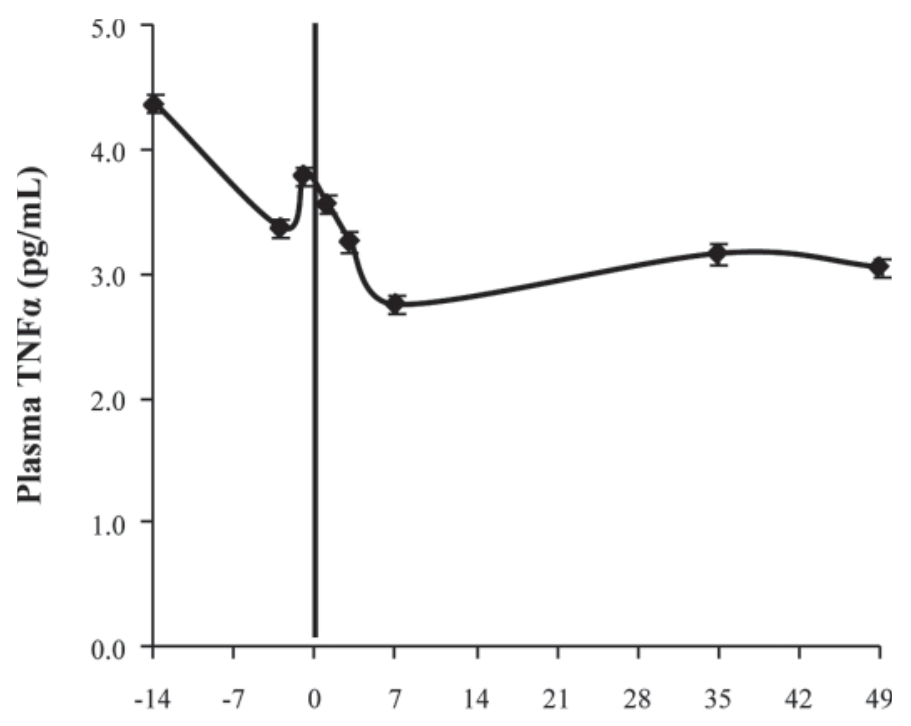

Day relative to parturition

Figure 4. Pre- and postpartum plasma tumor necrosis factor- $\alpha$ (TNF $\alpha$ ) of cows administered increasing amounts of thiazolidinediones (TZD) during the prepartum period. Data shown are mean plasma values from $\mathrm{d}-14$ through $\mathrm{d}+49$ relative to calving date. The vertical line represents the day of parturition. Values represent least squares means, with error bars representing the SEM; $\mathrm{n}=31$. Treatment effects are illustrated in Figure 4 . The $P$-value for the effect of day was 0.001 . $\mathrm{mg}$ of TZD $/ \mathrm{kg}$ of BW had the most substantial decrease in plasma leptin, and cows treated at the highest dose had similar leptin levels to those of control cows (Figure 1). Leptin mRNA in adipocytes is decreased by TZD (Hammarstedt et al., 2005), so the reason for differential effects based on treatment in this case is unclear. Although insulin was reported to increase plasma leptin during the transition period (Leury et al., 2003), changes in insulin are not likely to be a factor here, as circulating insulin levels prepartum were not different in these cows (Smith et al., 2009). Prepartum

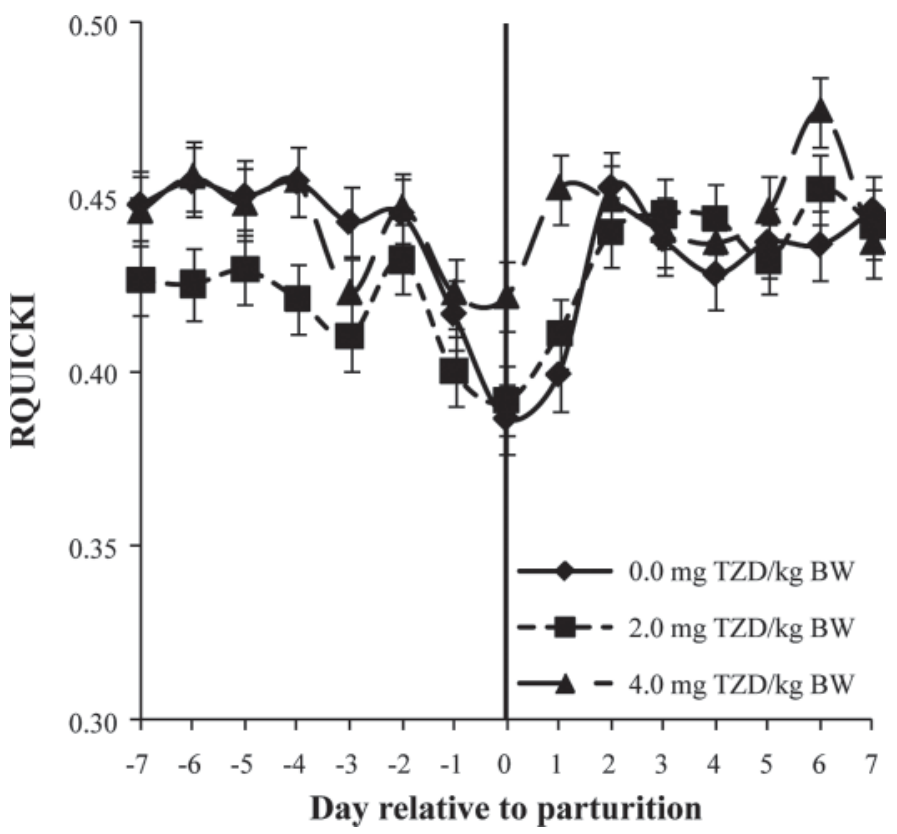

Figure 5. Peripartal revised quantitative insulin sensitivity check index (RQUICKI) of cows administered increasing amounts of thiazolidinediones (TZD) during the prepartum period. RQUICKI was calculated as follows: RQUICKI $=1 /[\log ($ glucose $)+\log$ (insulin) $+\log (\mathrm{NEFA})]$ for $7 \mathrm{~d}$ pre- and postcalving. Vertical line represents day of parturition. Values represent least squares means, with error bars representing the SEM; $\mathrm{n}=12$ for $0.0 \mathrm{mg}$ of $\mathrm{TZD} / \mathrm{kg}$ of $\mathrm{BW}, \mathrm{n}=10$ for $2.0 \mathrm{mg}$ of TZD $/ \mathrm{kg}$ of $\mathrm{BW}$, and $\mathrm{n}=9$ for $4.0 \mathrm{mg}$ of TZD $/ \mathrm{kg}$ of BW. The $P$-value for interaction of treatment and day was 0.09 , effect of day was $<0.001$, and effect of treatment was 0.38 . 
net energy balance (as percentage of requirements) according to the NRC (2001) was reported previously as $150 \%$ for control cows, $154 \%$ for cows receiving 2.0 $\mathrm{mg}$ of $\mathrm{TZD} / \mathrm{kg}$ of $\mathrm{BW}$, and $162 \%$ for cows receiving the highest dose, despite the absence of significant differences in prepartum DMI (Smith et al., 2009). It is possible some interaction with energy balance and TZD administration occurs prepartum, although energy balance differences here might not be significant. During the peripartum period, effects of treatment on plasma leptin were not significant, but the effect of day illustrates the normal plasma leptin response reported during this period (Block et al., 2001), the effects of which may overshadow treatment effects. Plasma leptin was approximately $3.2 \mathrm{ng} / \mathrm{mL}$ during the prepartum period, decreased to approximately $2.8 \mathrm{ng} / \mathrm{mL}$ around the time of calving, and remained lower at approximately 2.3 $\mathrm{ng} / \mathrm{mL}$ in the week following calving.

Although TZD administration had no effect on plasma leptin during the peripartum period, plasma leptin differed in the postpartum period. Additionally, milk production tended to be lower in cows administered $4.0 \mathrm{mg}$ of $\mathrm{TZD} / \mathrm{kg}$ of $\mathrm{BW}$ and yields of $3.5 \% \mathrm{FCM}$ were decreased (Smith et al., 2009). These differences in production may have resulted in perpetuating carryover effects on energy status for cows administered TZD prepartum, despite no differences in energy balance measured during the postpartum period. Due to a lack of difference in calculated postpartum energy balance, the linear increase in postpartum plasma leptin for TZD-treated cows (Figure 2) is more likely related to postpartum BCS. Figure 6 shows plasma leptin plotted with postpartum BCS. Circulating leptin has been shown to be higher in cattle with higher BCS (Ehrhardt et al., 2000). It is possible that in this case the higher plasma leptin is manifested through indirect effects that TZD administration had on energy balance during the pre- and peripartum periods. This may also explain in part how TZD administration prepartum can have lasting effects through early lactation.

Another potentially relevant plasma protein is TNFa. Tumor necrosis factor- $\alpha$ was used previously to induce insulin resistance in steers (Kushibiki et al., 2001). The role of TNFo in development of insulin resistance has been shown to be mediated through 1 of 2 TNF $\alpha$ receptors, TNFa receptor type 1 (Liang et al., 2008). As reviewed by Cawthorn and Sethi (2008), the action of $\mathrm{TNF} \alpha$ also involves events mediated through nuclear factor $\kappa-\mathrm{B}$. The potential relationship between $\mathrm{TNF} \alpha$, insulin resistance, inflammation, and TZD is further explained by experimental evidence in aged rats that nuclear factor $\kappa-\mathrm{B}$ is downregulated by, and thus mediates, the antiinflammatory effects of TZD (Sung et al., 2006). Thiazolidinediones have been shown to decrease
TNFo circulation and activity (Arner, 2003), likely attributing partially to the insulin-sensitizing effects of TZD administration. Thiazolidinediones have also been shown to have antiinflammatory effects in vitro (Revelo and Waldron, 2010). In this study, however, TZD administration increased plasma TNF (Figure 3). The relationship of TZD administration on TNF $\alpha$ in ruminants has not been determined, and TNF $\alpha$ itself remains relatively unstudied in dairy cattle. Given the surprising results here of increased TNFo with TZD administration, this area warrants further investigation. Tumor necrosis factor- $\alpha$ has been implicated in insulin resistance and fatty liver in transition cows (Ohtsuka et al., 2001), as well as during acute mastitis challenges in cows in early lactation (Blum et al., 2000).

Interestingly, circulating concentrations of $\mathrm{TNF} \alpha$ did decrease as parturition approached and were relatively higher prepartum compared with postpartum, as depicted in Figure 4. Increased circulating levels of $\mathrm{TNF} \alpha$ have been associated with increased circulating levels of leptin (Arner, 2003), and so it is not surprising that we see similar relationships over time. The TNFa analysis completed here was completed with a relatively new

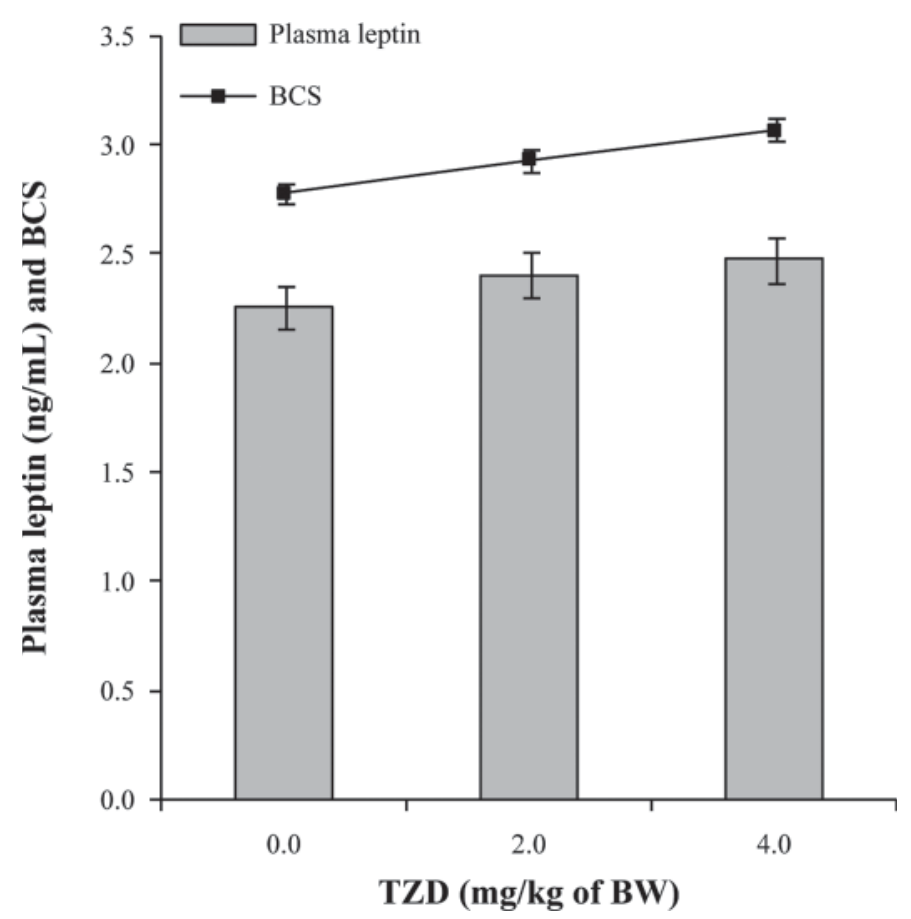

Figure 6. Postpartum plasma leptin and BCS of cows administered increasing amounts of thiazolidinediones (TZD) during the prepartum period. Data shown are average plasma values from $d+1$ through $d$ +49 relative to calving date and the average BCS from 2 scorers (Smith et al., 2009). Values represent least squares means, with error bars representing the SEM; $\mathrm{n}=12$ for $0.0 \mathrm{mg}$ of TZD $/ \mathrm{kg}$ of $\mathrm{BW}, \mathrm{n}=$ 10 for $2.0 \mathrm{mg}$ of TZD $/ \mathrm{kg}$ of BW, and $\mathrm{n}=9$ for $4.0 \mathrm{mg}$ of TZD $/ \mathrm{kg}$ of $\mathrm{BW}$. The $P$-value for a linear effect of treatment was 0.14 for plasma leptin and $<0.001$ for BCS. 
assay designed to detect much lower levels of $\mathrm{TNF} \alpha$ than were previously measured by bioassay and radioimmunoassay (Blum et al., 2000; Ohtsuka et al., 2001). Basal levels of $\mathrm{TNF} \alpha$ are relatively low in the absence of infection (Blum et al., 2000). As few studies have been able to examine the patterns of $\mathrm{TNF} \alpha$ at these lower levels, the pattern shown around the time of calving is worth further investigation.

A lower RQUICKI value is associated with greater insulin resistance (Holtenius and Holtenius, 2007). In this study, RQUICKI values decreased as calving approached and then increased again slightly through early lactation (Figure 5). This is in agreement with past statements regarding increased insulin resistance in the late prepartum period, as well as RQUICKI calculations in transition cows (Kerestes et al., 2009). Regarding the effects of TZD administration on RQUICKI, RQUICKI was highest around calving for cows administered the 4.0 mg dose of TZD and lowest precalving for cows receiving the $2.0 \mathrm{mg}$ dose (Figure 5). Although RQUICKI has been associated with changes in BCS, further research is required to confirm that cows with lower RQUICKI do indeed have greater insulin resistance. Authors of a previous paper attempted to correlate RQUICKI with results obtained during glucose tolerance test and insulin challenges (as proxies for relative insulin resistance) and concluded that RQUICKI is a poor indicator of insulin resistance, especially in cows experiencing poor metabolic health (Kerestes et al., 2009). Given the nature of the calculation, changes in plasma NEFA are likely to drive changes in RQUICKI. For instance, the cows in this study had, on average, peripartum insulin concentrations that decreased from approximately 1.2 to $0.60 \mathrm{ng} / \mathrm{mL}$ from $1 \mathrm{wk}$ before to 1 wk after parturition. During the same period, glucose concentrations decreased from approximately 66 to $48 \mathrm{mg} / \mathrm{dL}$, whereas the plasma NEFA concentration more than doubled, from approximately 120 to $345 \mu \mathrm{Eq} / \mathrm{L}$. We would expect changes in plasma NEFA to have direct and indirect effects on insulin resistance, so RQUICKI may be an applicable relative measure of insulin resistance. It would be premature to use RQUICKI to measure insulin resistance quantitatively in cows under different physiological states or management strategies, but its future as a general indicator is still unknown.

Although TZD is a known ligand for PPAR $\gamma$ (Houseknecht et al., 2002), this is the first evidence that TZD administration up-regulates mRNA expression for PPAR $\gamma$ in dairy cattle (Table 1 ). In addition to altering the expression of PPAR $\gamma$ mRNA, TZD had a significant effect on leptin mRNA (Table 1). Although the reasons for the differential leptin expression based on level of TZD treatment are not apparent, it is very interesting to note that patterns of mRNA expression are in agreement with prepartum plasma leptin data (Figure 1). Adipose tissue gene expression may have been affected by actual day relative to calving when biopsies were taken, as well as BCS. Because adipose tissue samples were taken at $\mathrm{d}-7$ relative to expected calving date, some variation was observed in actual day relative to calving that adipose tissue was collected. Day of adipose tissue biopsy relative to actual calving ranged from 2 to $13 \mathrm{~d}$. Especially for leptin, this is a period of dynamic change and, in the span of 1 or 2 $\mathrm{d}$, the major regulatory signals could be very different. For PPAR $\gamma$ mRNA, BCS was determined to be a significant covariate $(P=0.02)$ and was therefore included in the statistical model, whereas day relative to actual calving date was not $(P=0.79)$. For leptin expression, although day before actual calving date was a factor initially $(P=0.11)$, it was not significant in the final model $(P=0.16)$, and so was eventually dropped. Body condition score was not a significant covariate $(P$ $=0.28$ ) for statistical analysis of leptin expression. So, although it was hypothesized that BCS and day relative to actual calving date may be clouding treatment effects, in almost all cases, the influence did not reach levels that were statistically significant.

Because the enzyme activities of both LPL and FAS were regulated by pretranslational mechanisms, the activities corresponding well with mRNA levels (Hocquette et al., 1998; Bonnet et al., 1998), we would expect mRNA expression data in this study to reflect changes in enzyme activity. Administration of TZD had no effect on expression of LPL in this study. Although TZD has been shown to increase expression of LPL in nonruminants (Kageyama et al., 2003; Bogacka et al., 2004), its effects in ruminants are not yet known. Additionally, FAS expression has been shown to be increased by TZD administration in nonruminants (Bogacka et al., 2004), although in this case it appears to have been decreased by TZD administration in dairy cattle (Table 1). Because both of these genes have been implicated in changes in lipid metabolism occurring during milk fat depression (Harvatine et al., 2009), we hypothesized that they may play roles in changes in insulin resistance mediated by TZD administration. In this case, however, effects of treatment were not significant for LPL and were opposite to that expected for FAS. In the case of LPL, it may not be a large factor in early lactation but instead may play a greater regulatory role in mid to late lactation (McNamara et al., 1987). Other factors besides LPL and FAS appear to be altering lipid metabolism in response to TZD administration. Other potential targets may include hormone-sensitive lipase or phosphoenolpyruvate carboxykinase (PEPCK). The cytosolic form of PEPCK has been shown to be increased with TZD, resulting in decreased fatty acid 
release (Tordjman et al., 2003). This effect is likely a major factor in the effect of TZD on insulin resistance and is a logical next step in exploring regulation of fatty acid metabolism during insulin resistance and potential mediation by TZD. The potential also exists to explore how additional adipokines besides leptin and TNFo are affected by TZD administration in dairy cattle. One example would be adiponectin, which has been shown in humans to be increased by TZD (Tonelli et al., 2004) and may be an important regulator in the transition to early lactation (Lemor et al., 2009). Furthermore, adipose tissue depots in addition to subcutaneous white adipose tissue near the tailhead may have additional influence on measures related to insulin sensitivity investigated here. As reviewed by Arner (2003), visceral adipose tissue may differ in terms of fatty acid metabolism, secretion of adipokines, and response to TZD administration. Future investigation into the role of additional adipose tissue depots in dairy cattle would be worthwhile.

\section{CONCLUSIONS}

Prepartum administration of TZD in transition dairy cattle has been shown to improve DMI and metabolic health (as measured by attenuated loss in BCS postcalving and reduced days to first ovulation; Smith et al., 2007, 2009). Results shown here add to these previous bodies of work. Expression of PPAR $\gamma$ mRNA was up-regulated by TZD administration. Additional results reported herein illustrate that TZD directly or indirectly alters leptin mRNA expression in adipose tissue and its circulating peripartal concentrations. Plasma concentrations of TNF $\alpha$ were increased linearly by TZD administration, in patterns potentially opposite to results shown in nonruminants. Although TZD had no significant effect on RQUICKI, RQUICKI did vary based on day relative to parturition. The relationship of RQUICKI and day relative to calving is consistent with the timing of insulin resistance and $\mathrm{TNF} \alpha$ concentration around the time of calving, suggesting that RQUICKI might have potential as a qualitative measure of insulin resistance in dairy cattle. Given mixed results in this experiment and others reported, the need exists to evaluate RQUICKI further before it is used regularly as a measure of insulin resistance in ruminants. Administration of TZD had no effect on expression of LPL, and the pattern of response in gene expression of FAS may be opposite to that seen in nonruminants. This study suggests that factors other than leptin, TNFo, LPL, and FAS activity play a role in the effects of TZD administration on the metabolic health of transition dairy cows. The study does, however, illustrate the importance of leptin, $\mathrm{TNF} \alpha$, and insulin sensitivity in temporal changes in the periparturient dairy cow.

\section{ACKNOWLEDGMENTS}

The authors sincerely appreciate the contribution of the following individuals for completion of this trial: R. Ehrhardt, S. L. Giesy, and the staff at the Cornell University Dairy Teaching and Research Center.

\section{REFERENCES}

Arner, P. 2003. The adipocyte in insulin resistance: Key molecules and the impact of the thiazolidinediones. Trends Endocrinol. Metab. 14:137-145.

Bauman, D. E., and W. B. Currie. 1980. Partitioning of nutrients during pregnancy and lactation: A review of mechanisms involving homeostasis and homeorhesis. J. Dairy Sci. 63:1514-1529.

Bell, A. W. 1995. Regulation of organic nutrient metabolism during transition from late pregnancy to early lactation. J. Anim. Sci. 73:2804-2819.

Bell, A. W., and D. E. Bauman. 1997. Adaptations of glucose metabolism during pregnancy and lactation. J. Mammary Gland Biol. Neoplasia 2:265-278.

Block, S. S., W. R. Butler, R. A. Ehrhardt, A. W. Bell, M. E. Van Amburgh, and Y. R. Boisclair. 2001. Decreased concentration of plasma leptin in periparturient dairy cows is caused by negative energy balance. J. Endocrinol. 171:339-348.

Blum, J. W., H. Dosogne, D. Hoeben, F. Vangroenweghe, H. M. Hammon, R. M. Bruckmaier, and C. Burvenich. 2000. Tumor necrosis factor-[alpha] and nitrite/nitrate responses during acute mastitis induced by Escherichia coli infection and endotoxin in dairy cows. Domest. Anim. Endocrinol. 19:223-235.

Bobe, G., J. W. Young, and D. C. Beitz. 2004. Invited review: Pathology, etiology, prevention, and treatment of fatty liver in dairy cows. J. Dairy Sci. 87:3105-3124.

Bogacka, I., H. Xie, G. A. Bray, and S. R. Smith. 2004. The effect of pioglitazone on peroxisome proliferator-activated receptor-gamma target genes related to lipid storage in vivo. Diabetes Care 27:1660-1667.

Bonnet, M., Y. Faulconnier, J. Flechet, J. F. Hocquette, C. Leroux, D. Langin, P. Martin, and Y. Chilliard. 1998. Messenger RNAs encoding lipoprotein lipase, fatty acid synthase and hormone-sensitive lipase in the adipose tissue of underfed-refed ewes and cows. Reprod. Nutr. Dev. 38:297-307.

Cawthorn, W. P., and J. K. Sethi. 2008. TNF-[alpha] and adipocyte biology. FEBS Lett. 582:117-131.

Drackley, J. K. 1999. ADSA Foundation Scholar Award: Biology of dairy cows during the transition period: The final frontier? J. Dairy Sci. 82:2259-2273.

Drackley, J. K., T. R. Overton, and G. N. Douglas. 2001. Adaptations of glucose and long-chain fatty acid metabolism in liver of dairy cows during the periparturient period. J. Dairy Sci. 84(E. Suppl.):E100-E112.

Ehrhardt, R. A., R. M. Slepetis, J. Siegal-Willott, M. E. Van Amburgh, A. W. Bell, and Y. R. Boisclair. 2000. Development of a specific radioimmunoassay to measure physiological changes of circulating leptin in cattle and sheep. J. Endocrinol. 166:519-528.

Farney, J. K., L. K. Mamedova, B. H. Godsey, and B. J. Bradford. 2011. Technical note: Validation of an ELISA for measurement of tumor necrosis factor alpha in bovine plasma. J. Dairy Sci. 94:3504-3509.

Guo, L., and R. Tabrizchi. 2006. Peroxisome proliferator-activated receptor gamma as a drug target in the pathogenesis of insulin resistance. Pharmacol. Ther. 111:145-173.

Hammarstedt, A., C. X. Andersson, V. Rotter Sopasakis, and U. Smith. 2005. The effect of PPARgamma ligands on the adipose tissue in insulin resistance. Prostaglandins Leukot. Essent. Fatty Acids 73:65-75. 
Harvatine, K. J., and D. E. Bauman. 2006. SREBP1 and thyroid hormone responsive spot 14 (S14) are involved in the regulation of bovine mammary lipid synthesis during diet-induced milk fat depression and treatment with CLA. J. Nutr. 136:2468-2474.

Harvatine, K. J., and D. E. Bauman. 2007. Expression of PPAR and LXR nuclear hormone receptor families are not modified during milk fat depression induced by diet or treatment with trans-10, cis-12 conjugated linoleic acid (CLA). J. Dairy Sci. 90(Suppl. 1):59. (Abstr.)

Harvatine, K. J., J. W. Perfield, and D. E. Bauman. 2009. Expression of enzymes and key regulators of lipid synthesis is upregulated in adipose tissue during CLA-induced milk fat depression in dairy cows. J. Nutr. 139:849-854.

Hocquette, J. F., B. Graulet, and T. Olivecrona. 1998. Lipoprotein lipase activity and mRNA levels in bovine tissues. Comp. Biochem. Physiol. B Biochem. Mol. Biol. 121:201-212.

Holtenius, P., and K. Holtenius. 2007. A model to estimate insulin sensitivity in dairy cows. Acta Vet. Scand. 49:29-31.

Houseknecht, K. L., B. M. Cole, and P. J. Steele. 2002. Peroxisome proliferator-activated receptor gamma (PPARgamma) and its ligands: A review. Domest. Anim. Endocrinol. 22:1-23.

Kageyama, H., T. Hirano, K. Okada, T. Ebara, A. Kageyama, T. Murakami, S. Shioda, and M. Adachi. 2003. Lipoprotein lipase mRNA in white adipose tissue but not in skeletal muscle is increased by pioglitazone through PPAR-gamma. Biochem. Biophys. Res. Commun. 305:22-27.

Kerestes, M., V. Faigl, M. Kulcsar, O. Balogh, J. Foldi, H. Febel, Y. Chilliard, and G. Huszenicza. 2009. Periparturient insulin secretion and whole-body insulin responsiveness in dairy cows showing various forms of ketone pattern with or without puerperal metritis. Domest. Anim. Endocrinol. 37:250-261.

Kushibiki, S., K. Hodate, H. Shingu, Y. Ueda, M. Shinoda, Y. Mori, T. Itoh, and Y. Yokomizo. 2001. Insulin resistance induced in dairy steers by tumor necrosis factor alpha is partially reversed by 2,4-thiazolidinedione. Domest. Anim. Endocrinol. 21:25-37.

Lemor, A., A. Hosseini, H. Sauerwein, and M. Mielenz. 2009. Transition period-related changes in the abundance of the mRNAs of adiponectin and its receptors, of visfatin, and of fatty acid binding receptors in adipose tissue of high-yielding dairy cows. Domest. Anim. Endocrinol. 37:37-44.

Leury, B. J., L. H. Baumgard, S. S. Block, N. Segoale, R. A. Ehrhardt, R. P. Rhoads, D. E. Bauman, A. W. Bell, and Y. R. Boisclair. 2003. Effect of insulin and growth hormone on plasma leptin in periparturient dairy cows. Am. J. Physiol. Regul. Integr. Comp. Physiol. 285:R1107-R1115.

Liang, H., B. Yin, H. Zhang, S. Zhang, Q. Zeng, J. Wang, X. Jiang, L. Yuan, C. Y. Wang, and Z. Li. 2008. Blockade of tumor necrosis factor (TNF) receptor type 1-mediated TNF-alpha signaling protected Wistar rats from diet-induced obesity and insulin resistance. Endocrinology 149:2943-2951.

Liefers, S. C., R. F. Veerkamp, M. F. W. te Pas, C. Delavaud, Y. Chilliard, and T. van der Lende. 2003. Leptin concentrations in relation to energy balance, milk yield, intake, live weight, and estrus in dairy cows. J. Dairy Sci. 86:799-807.

McCutcheon, S. N., and D. E. Bauman. 1986. Effect of chronic growth hormone treatment on responses to epinephrine and thyrotropinreleasing hormone in lactating cows. J. Dairy Sci. 69:44-51.
McNamara, J. P., D. C. McFarland, and S. Bai. 1987. Regulation of bovine adipose tissue metabolism during lactation. 3. Adaptations of hormone-sensitive and lipoprotein lipases. J. Dairy Sci. 70:1377-1384

NRC. 2001. Nutrient Requirements of Dairy Cattle. 7th rev. ed. Natl. Acad. Press, Washington, DC.

Ohtsuka, H., M. Koiwa, A. Hatsugaya, K. Kudo, F. Hoshi, N. Itoh, H. Yokota, H. Okada, and S. Kawamura. 2001. Relationship between serum TNF activity and insulin resistance in dairy cows affected with naturally occurring fatty liver. J. Vet. Med. Sci. 63:1021-1025

Revelo, X. S., and M. R. Waldron. 2010. Effects of in vitro insulin and 2,4-thiazolidinedione on the function of neutrophils harvested from blood of cows in different physiological states. J. Dairy Sci. 93:3990-4005.

Smith, K. L., W. R. Butler, and T. R. Overton. 2009. Effects of prepartum 2,4-thiazolidinedione on metabolism and performance in transition dairy cows. J. Dairy Sci. 92:3623-3633.

Smith, K. L., S. E. Stebulis, M. R. Waldron, and T. R. Overton. 2007. Prepartum 2,4-thiazolidinedione alters metabolic dynamics and dry matter intake of dairy cows. J. Dairy Sci. 90:3660-3670.

Sundvold, H., A. Brzozowska, and S. Lien. 1997. Characterisation of bovine peroxisome proliferator-activated receptors gamma 1 and gamma 2: Genetic mapping and differential expression of the two isoforms. Biochem. Biophys. Res. Commun. 239:857-861.

Sung, B., S. Park, B. P. Yu, and H. Y. Chung. 2006. Amelioration of age-related inflammation and oxidative stress by PPAR[gamma] activator: Suppression of NF-[kappa]B by 2,4-thiazolidinedione. Exp. Gerontol. 41:590-599.

Thorn, S. R., S. Purup, W. S. Cohick, M. Vestergaard, K. Sejrsen, and Y. R. Boisclair. 2006. Leptin does not act directly on mammary epithelial cells in prepubertal dairy heifers. J. Dairy Sci. 89:1467-1477.

Tonelli, J., W. Li, P. Kishore, U. B. Pajvani, E. Kwon, C. Weaver, P. E. Scherer, and M. Hawkins. 2004. Mechanisms of early insulinsensitizing effects of thiazolidinediones in type 2 diabetes. Diabetes 53:1621-1629.

Tordjman, J., W. Khazen, B. Antoine, G. Chauvet, J. Quette, F. Fouque, E. G. Beale, C. Benelli, and C. Forest. 2003. Regulation of glyceroneogenesis and phosphoenolpyruvate carboxykinase by fatty acids, retinoic acids and thiazolidinediones: Potential relevance to type 2 diabetes. Biochimie 85:1213-1218.

Vernon, R. G. 2005. Lipid metabolism during lactation: A review of adipose tissue-liver interactions and the development of fatty liver. J. Dairy Res. 72:460-469.

Vernon, R. G., R. G. Denis, and A. Sorensen. 2001. Signals of adiposity. Domest. Anim. Endocrinol. 21:197-214.

Wildman, E. E., G. M. Jones, P. E. Wagner, R. L. Boman, J. Troutt, and T. N. Lesch. 1982. A dairy cow body condition scoring system and its relationship to selected production characteristics. J. Dairy Sci. 65:495-501.

Yki-Jarvinen, H. 2004. Thiazolidinediones. N. Engl. J. Med 351:1106-1118. 